\title{
Hubungan Status Sosial Ekonomi dan Gaya Hidup dengan Kejadian Obesitas pada Siswa SD Negeri 08 Alang Lawas Padang
}

\author{
Cici Octari, Nur Indrawaty Liputo, Edison
}

\begin{abstract}
Abstrak
Obesitas di Indonesia mulai menjadi masalah gizi masyarakat walaupun gizi kurang masih tinggi. Obesitas disebabkan oleh banyak faktor/multifaktorial yang dapat dibagi menjadi genetik dan lingkungan yang diantaranya adalah status sosial ekonomi dan gaya hidup. Penelitian ini menggunakan desain cross sectional study dengan populasi adalah seluruh siswa kelas I sampai V di SD N 08 Alang Lawas,Padang. Penelitian ini mendapatkan hasil $8,21 \%$ siswa mengalami obesitas, $11,79 \%$ overweight atau gemuk, 82,60\% tingkat pendapatan orang tua siswa berada di atas garis kemiskinan, $71,30 \%$ ayah dan $71,80 \%$ ibu siswa memiliki tingkat pendidikan menengah, 58,50\% siswa memiliki pola makan baik, dan $60 \%$ memiliki aktifitas fisik aktif. Tidak didapatkan hubungan yang bermakna antara kejadian obesitas dengan tingkat pendidikan orang tua (ayah: $p=0,205$; ibu: $p=1,00$ ), tingkat pendapatan orang tua $(p=0,396)$, dan pola makan anak $(p=0,245)$. Didapatkan hubungan yang bermakna antara aktifitas fisik anak dengan kejadian obesitas $(p=0,048)$.
\end{abstract}

Kata kunci: obesitas, anak, sosial-ekonomi, gaya hidup

\begin{abstract}
In Indonesia, obesity has became a public nutrition problem although frequence of undernutrition was still high. The obesity caused by many factor/multifactorial that asssigned to genetic factor and environment factor. Two of the environment factors are social-economy and life style. Cross sectional study was chosen as a method to conduct the study. The study population were all the students on 1st grade to 5th grade in SD Negeri 08 Alang Lawas, Padang. The result shows that $8.21 \%$ of the students suffered from obesity, $11.79 \%$ were overweight, $82.60 \%$ of the students have the parents that have income more then the poverty line, $71.30 \%$ of the fathers and $71.80 \%$ of the mothers were middle graduations, $58.50 \%$ have good consumptions pattern, and $60 \%$ have active physical activity. There are no association between the obesity among the children with parent's graduation (father: $p=0.205$; mother: $p=1.00$ ), parent's income $(p=0.396)$, consumptions pattern $(p=0.245)$, and there is association with physical activity $(p=0.048)$.

Keywords:obesity, children, social-economy, life style
\end{abstract}

Affiliasi penulis : Fakultas Kedokteran Universitas Andalas Korespondensi :Cici Octari, Email: octa_rhy@yahoo.com, Telp: 081363699779

\section{PENDAHULUAN}

Obesitas adalah suatu keadaan di mana terjadi penimbunan lemak tubuh secara berlebihan sehingga berat badan tubuh seseorang jauh di atas normal, hal ini akibat ketidakseimbangan asupan (intake) dan pemakaian (expenditure) energi. ${ }^{1,2}$ WHO telah menyatakan obesitas telah menjadi epidemi global, sehingga merupakan suatu masalah kesehatan yang harus ditangani segera. ${ }^{1}$ Kejadian obesitas di Indonesia mulai menjadi masalah gizi di masyarakat walaupun gizi kurang atau kurus masih tinggi. Prevalensi balita gemuk mengalami peningkatan dari 12,2\% pada tahun 2007 menjadi $14,0 \%$ pada tahun 2010. Begitu juga pada usia anak sekolah (6-12 tahun), prevalensi kegemukan masih tinggi $(>5,0 \%)$ yaitu $9,2 \%$. Angka kegemukan anak usia sekolah di Sumatera Barat berdasarkan hasil Riskesdas 2010 masih berada di bawah prevalensi nasional yaitu $3,8 \%{ }^{3}$ Berdasarkan hasil skrining kesehatan murid sekolah dasar Kota Padang tahun 2011 didapatkan angka gizi lebih pada anak sekolah dasar di Kota Padang adalah $7,4 \%$ dan obesitas sebesar $1,7 \%{ }^{4}$
Banyak faktor yang berperan dalam terjadinya obesitas yang sebagian besar merupakan interaksi antara faktor genetik dengan faktor lingkungan, antara lain aktivitas fisik, sosial ekonomi, dan nutrisi. Perubahan gaya hidup menyebabkan terjadinya perubahan pengetahuan, sikap, perilaku, pola makan, serta pemilihan jenis dan jumlah makanan yang dikonsumsi. Selain itu perubahan gaya hidup juga menurunkan frekuensi dan intensitas aktivitas fisik yang dilakukan. Terjadi penurunan aktivitas fisik ini dapat dilihat dari penurunan intensitas olahraga dan permainan yang mempergunakan fisik pada anak digantikan dengan jenis permainan elektronik seperti video game.

Dilihat dari karakteristik responden pada angka kegemukan anak usia sekolah lebih banyak terjadi pada anak dengan pendapatan keluarga tetap atau stabil. Tampak hubungan semakin meningkatnya keadaan ekonomi dengan peningkatan angka kejadian kegemukan atau obesitas ini. Selain itu juga terjadi peningkatan angka kejadian seiring dengan meningkatnya tingkat pendidikan kepala rumah tangga. $^{3}$

Padang memiliki tingkat penghasilan rata-rata tertinggi untuk wilayah Sumatera Barat. Serta status Kota Padang sebagai ibukota provinsi menyebabkan 
terjadinya peningkatan taraf hidup yang mendorong ke arah perubahan gaya hidup menjadi lebih modern. Hal ini akan diikuti oleh peningkatan daya beli masyarakat dan pola konsumsi anak. Peningkatan ini menjadi alasan menjamurnya restoran siap saji modern dan semakin bervariasinya jajanan anak di sekolah dasar. Anggapan bahwa terbiasa mengkonsumsi makanan tersebut mengangkat status sosial menjadi masyarakat modern menyebabkan meningkatnya jumlah konsumsi makanan ini. Ditambah dengan semakin mudahnya untuk mendapatkan makanan siap saji atau junk food dengan harga yang semakin terjangkau oleh masyarakat. Hal-hal ini yang dapat menyebabkan semakin tingginya prevalensi kejadiaan obesitas pada anak.

Obesitas memiliki banyak komorbiditas/komplikas (risk of obesity-related diseases) baik pada saat masa anak-anak maupun yang akan timbul saat masa dewasa. Obesitas pada anak memiliki kecenderungan untuk berlanjut hingga dewasa terutama apabila kemunculannya pada anak usia 4-11 tahun (usia sekolah). Obesitas yang menetap hingga dewasa akan memicu timbulnya beberapa penyakit seperti penyakit degeneratif. Sehingga perlu dilakukan upaya pencegahan terjadinya gizi lebih dan obesitas sejak dini (usia sekolah). ${ }^{5}$ Tujuan penelitian ini adalah untuk menganalisis hubungan status sosial-ekonomi dan gaya hidup dengan kejadian obesitas pada anak yang dilaksanakan di SD Negeri 08 Alang Lawas, kec. Padang Selatan, Padang.

\section{METODE}

Jenis penelitian adalah survei analitik dengan desain cross sectional study. Populasi penelitian adalah siswa SD Negeri 08 Alang Lawas Padang yang duduk di kelas I hingga kelas $\mathrm{V}$ tahun ajaran 2012/2013 yang berjumlah 376 orang. Sampel berjumlah 195 orang yang dibagi secara proporsi untuk masing-masing tingkatan kelas. Didapatkan jumlah sampel 41 untuk kelas I, kelas II 40, kelas III 38, kelas IV 39 , dan kelas V 37 sampel yang kemudian akan dipilih dengan metode simple random sampling.

Variabel dependen penelitian adalah obesitas yang dinilai berdasarkan IMT/U sesuai dengan baku rujukan WHO 2005. IMT/U diklasifikasikan menjadi sangat kurus $(<-3 S D)$, kurus $(-3 S D$ s/d $<-2 S D)$, normal (-2SD s/d 1SD), gemuk/overweight (>1SD s/d 2SD), dan obesitas (>2SD). ${ }^{6}$ Pada penelitian ini yang akan dianalisis sebagai obes adalah IMT/U yang diklasifikasikan gemuk/overweight dan obesitas, serta tidak obes adalah sangat kurus, kurus, dan normal. Alat yang digunakan untuk menimbang berat badan anak yaitu timbangan injak dengan kapasitas $150 \mathrm{~kg}$ dan ketelitian $0,1 \mathrm{~kg}$. Alat yang digunakan untuk mengukur tinggi badan anak adalah microtoise dengan kepekaan $0,1 \mathrm{~cm}$. Variabel independen adalah tingkat pendidikan orang tua, tingkat pendapatan orang tua, pola makan, dan aktifitas fisik yang dikumpulkan dengan kuesioner.

Langkah-langkah pengolahan data yang dilakukan yaitu memeriksa kelengkapan data dari kuesioner, memberikan kode pada setiap data variabel yang telah terkumpul, memasukkan data ke dalam komputer dengan program Microsoft Excell dan Statistical Program for Social Science (SPSS) 16.0, dan memeriksa kembali data yang telah dimasukkan untuk memastikan bahwa data tersebut telah bersih dari kesalahan. Analisis data terdiri dari analisis univariat dan bivariat. Analisis bivariat digunakan untuk mengetahui hubungan antara dua variabel menggunakan uji Chi-square dengan derajat kemaknaan $p<0,05{ }^{7}$

\section{HASILDANPEMBAHASAN}

1. Kejadian Obesitas di SD Negeri 08 Alang Lawas Padang

Dari penelitian ini didapatkan distribusi indeks massa tubuh (IMT) responden sebagai berikut.

Tabel 1. Distribusi Indeks Massa Tubuh (IMT) Siswa SDN 08 Alang Lawas, Padang

\begin{tabular}{lcc}
\hline \multicolumn{1}{c}{ IMT } & N & \% \\
\hline Sangat Kurus & 3 & 1.54 \\
Kurus & 4 & 2.05 \\
Normal & 149 & 76.41 \\
Berat Lebih/Gemuk & 23 & 11.79 \\
Obesitas & 16 & 8.21 \\
\hline Total & $\mathbf{1 9 5}$ & $\mathbf{1 0 0 . 0 0}$ \\
\hline
\end{tabular}

Tabel 1 memperlihatkan bahwa persentase klasifikasi Indeks Massa Tubuh (IMT) siswa terbanyak adalah normal yaitu $76,41 \%$. Obesitas $(8,21 \%)$ dan gemuk $(11,79 \%)$ lebih banyak apabila dibandingkan kurus dan sangat kurus. Pada penelitian ini yang digolongkan sebagai obesitas adalah siswa dengan Indeks Massa Tubuh (IMT) obesitas dan berat lebih atau gemuk sehingga didapatkan persentase sebesar $20 \%$. Hasil ini lebih besar dibandingkan dengan hasil skrining kesehatan yang dilakukan Dinas Kesehatan Kota Padang pada siswa sekolah dasar tahun 2011 yang (obesitas dan berat lebih 9,1\%). Persentase ini juga tinggi jika dibandingkan dengan hasil RISKESDAS tahun 2010 yang mendapatkan kegemukan pada anak usia sekolah (6-12 tahun) sebesar $9,2 \%$.

\section{Hubungan Tingkat Pendidikan Orang Tua dengan Kejadian Obesitas pada Anak}

Didapatkan untuk tingkat pendidikan ayah persentase terbanyak adalah $71,30 \%$ menengah. Analisis terhadap hubungan tingkat pendidikan orang tua dengan kejadian obesitas pada anak didapatkan hasil sebagai berikut :

Tabel 2. Hubungan Tingkat Pendidikan Orang Tua dengan Kejadian Obesitas pada Siswa SD N 08 Alang Lawas, Padang

\begin{tabular}{|c|c|c|c|c|c|c|c|}
\hline \multirow{3}{*}{$\begin{array}{c}\text { Tingkat } \\
\text { pendidikan } \\
\text { orang tua }\end{array}$} & \multicolumn{4}{|c|}{ Kejadian obesitas } & \multirow{2}{*}{\multicolumn{2}{|c|}{ Jumlah }} & \multirow{3}{*}{$\begin{array}{c}\mathbf{P} \\
\text { Value }\end{array}$} \\
\hline & \multicolumn{2}{|c|}{ Obesitas } & \multicolumn{2}{|c|}{$\begin{array}{c}\text { tidak } \\
\text { obesitas }\end{array}$} & & & \\
\hline & $\mathbf{n}$ & $\%$ & $\mathbf{n}$ & $\%$ & $\mathbf{n}$ & $\%$ & \\
\hline \multicolumn{8}{|l|}{ Ayah } \\
\hline Menengah & 31 & 22,30 & 108 & 77,70 & 139 & 100,00 & 0.205 \\
\hline Tinggi & 8 & 14,29 & 48 & 85,71 & 56 & 100,00 & \\
\hline Jumlah & 39 & 20,00 & 156 & 80,00 & 195 & 100,00 & \\
\hline \multicolumn{8}{|l|}{ Ibu } \\
\hline Menengah & 28 & 20,00 & 112 & 80,00 & 140 & 100,00 & 1.00 \\
\hline
\end{tabular}




\begin{tabular}{lrrrrrr} 
Tinggi & 11 & 20,00 & 44 & 80,00 & 55 & 100,00 \\
\hline Jumlah & 39 & 20,00 & 156 & 80,00 & 195 & 100,00
\end{tabular}

Berdasarkan tabel 2 dapat dilihat bahwa jumlah kejadian obesitas pada sampel dengan tingkat pendidikan ayah dan ibu menengah (31 dan 28 kejadian) lebih banyak dibandingkan sampel dengan tingkat pendidikan ayah dan ibu tinggi dan rendah.

Tingkat pendidikan ayah yang berperan sebagai kepala keluarga sangat mempengaruhi pola pendidikan dan asuhan orang tua terhadap anak di dalam rumah tangga. Selain itu tingkat pendidikan ayah dapat mempengaruhi dari jenis pekerjaan ayah yang memiliki pengaruh pada tingkat ekonomi keluarga yang juga mempengaruhi kemampuan orang tua memenuhi kebutuhan dan gaya hidup anak.

Uji statistik terhadap hubungan tingkat pendidikan ayah terhadap kejadian obesitas didapatkan tidak bermakna dengan $p$-value $=0,205$ ( $p>0,05$ ). Dapat disimpulkan bahwa tingkat pendidikan ayah tidak memiliki pengaruh terhadap kejadian obesitas pada anak. Hasil ini berbeda dengan hasil yang didapatkan pada penelitian Simatupang tahun 2008 dan penelitian Haryanto tahun 2012 yang mendapatkan hubungan yang bermakna antara tingkat pendidikan ayah dengan kejadian obesitas pada anak. Hasil ini dapat dipengaruhi oleh metode pengklasifikasian tingkat pendidikan yang digunakan pada penelitian ini berbeda dengan penelitian yang dilakukan oleh Simatupang. Selain itu, perbedaan sosial budaya masyarakat yang akan mempengaruhi juga peran ayah dalam keluarga pada lokasi penelitian dapat juga mempengaruhi hasil yang didapat.,

Tingkat pendidikan ibu akan berkaitan dengan pengetahuan dan pemahaman ibu terhadap kesehatan, nutrisi, dan hal lainnya untuk anak. Hal ini akan mempengaruhi pola asuh, pengaturan nutrisi, serta pemilihan jenis makanan yang berkontribusi terhadap terjadinya obesitas pada anak. Pada ibu dengan tingkat pendidikan lebih tinggi sangat diharapkan terjadi peningkatan pengetahuan dan pemahan terhadap pola asuh dan nutrisi yang baik untuk anak dibandingkan ibu dengan tingkat pendidikan yang lebih rendah. Tetapi dari uji statistik terhadap hubungan kejadian obesitas dengan tingkat pendidikan ibu didapatkan tidak bermakna dengan $p$ value $=1,00 \quad(p>0,05)$. Dari nilai tersebut dapat disimpulkan tidak adanya hubungan antara tingkat pendidikan ibu dengan kejadian obesitas pada anak. Hasil ini sesuai dengan dengan hasil penelitian Simatupang tahun 2008 yang menyatakan bahwa tidak terdapat hubungan yang bermakna antara pendidikan ibu dengan obesitas pada anak. Tetapi pada penelitian yang dilakukan oleh Haryanto pada tahun 2012 menemukan adanya hubungan yang bermakna antara tingkat pendidikan ibu dengan obesitas anak. Hal ini diduga adanya pengaruh dari tempat tinggal dan sosial budaya di lingkungan tempat tinggal yang berpengaruh pada pengetahuan dan pola asuh ibu. , $^{\circ}$

3. Hubungan Tingkat Pendapatan Orang Tua dengan Kejadian Obesitas pada Anak

Tingkat pendapatan orang tua berkaitan dengan kemampuan orang tua untuk mencukupi kebutuhan, pemilihan jenis dan jumlah makanan, serta berpengaruh terhadap gaya hidup keluarga yang juga akan berdampak pada anak. Aritonang berpendapat bahwa pendapatan yang tinggi tidak selalu menjamin beragam dan bermutunya bahan pangan yang dikonsumsi tetapi dapat juga mengarah pada pemilihan bahan makanan yang lebih enak, siap santap, cepat, dan lebih banyak mengandung lemak, minyak, dan bahan lainnya yang dapat menyebabkan obesitas. $^{10}$ Tingkat pendapatan diklasifikasikan berdasarkan pendapatan/kapita/bulan kota Padang pada data BPS tahun $2012 .^{9}$

Dari penelitian ini didapatkan pendapatan perkapita orang tua siswa yang menjadi responden $81,86 \%$ berada di atas garis kemiskinan dan $18,14 \%$ berada di bawah garis kemiskinan.

Tabel 3. Hubungan Tingkat Pendapatan Orang Tua dengan Kejadian Obesitas pada Siswa SD N 08 Alang Lawas, Padang

\begin{tabular}{|c|c|c|c|c|c|c|c|}
\hline \multirow{3}{*}{$\begin{array}{l}\text { Tingkat } \\
\text { pendapatan } \\
\text { orang tua }\end{array}$} & \multicolumn{4}{|c|}{ Kejadian obesitas } & \multirow{2}{*}{\multicolumn{2}{|c|}{ Jumlah }} & \multirow{3}{*}{$\begin{array}{c}\mathbf{P} \\
\text { Value }\end{array}$} \\
\hline & \multicolumn{2}{|c|}{ obesitas } & \multicolumn{2}{|c|}{$\begin{array}{c}\text { tidak } \\
\text { obesitas }\end{array}$} & & & \\
\hline & $\mathbf{n}$ & $\%$ & $\mathbf{n}$ & $\%$ & $\mathbf{n}$ & $\%$ & \\
\hline $\begin{array}{l}\text { di atas garis } \\
\text { kemiskinan } \\
\text { di bawah } \\
\text { garis } \\
\text { kemiskinan }\end{array}$ & 34 & 21,12 & 127 & 78,88 & 161 & 100,00 & 0.396 \\
\hline Jumlah & 39 & 20,00 & 156 & 80,00 & 195 & 100,00 & \\
\hline
\end{tabular}

Berdasarkan tabel 3 dapat dilihat bahwa kejadian obesitas lebih banyak pada sampel dengan tingkat pendapatan orang tua di atas garis kemiskinan (34 kejadian). Tetapi uji statistik terhadap hubungan tingkat pendapatan orang tua dengan obesitas pada anak tidak bermakna dengan $p$-value $=0,396(p>0,05)$. Dari hasil tersebut dapat disimpulkan bahwa tingkat pendapatan orang tua tidak berpengaruh terhadap kejadian obesitas pada anak. Hasil penelitian ini berbeda dengan penelitian yang dilakukan Hadi, dkk pada tahun 2005 yang mendapatkan tingkat pendapatan perkapita keluarga memiliki pengaruh terhadap kejadian obesitas pada anak. Perbedaan hasil penelitian ini dapat dipengaruhi oleh berbagai faktor salah satunya perbedaan jumlah sampel yang cukup jauh antara penelitian ini dengan penelitian yang dilakukan Hadi, dkk yaitu 215 sampel dan 44 sampel. ${ }^{10}$

\section{Hubungan Pola Makan dengan Kejadian} Obesitas pada Anak

Pola makan yang dikaji pada penelitian ini adalah frekuensi dan jenis makanan yang dikonsumsi oleh anak. Frekuensi dan jenis makanan yang dikonsumsi berpengaruh pada jumlah konsumsi kalori, lemak, serta nutrisi lain. Dari penelitian ini didapatkan $58,6 \%$ responden memiliki pola makan baik dan $41,4 \%$ memiliki pola makan tidak baik.

Tabel 4. Hubungan Pola Makan dengan Kejadian Obesitas pada Siswa SD N 08 Alang Lawas, Padang

\begin{tabular}{|c|c|c|c|c|c|c|c|}
\hline \multirow{3}{*}{$\begin{array}{l}\text { Pola } \\
\text { makan }\end{array}$} & \multicolumn{4}{|c|}{ Kejadian obesitas } & \multirow{2}{*}{\multicolumn{2}{|c|}{ Jumlah }} & \multirow{3}{*}{$\stackrel{P}{\mathbf{P}}$} \\
\hline & \multicolumn{3}{|c|}{ obesitas } & \multirow{2}{*}{$\begin{array}{c}\begin{array}{c}\text { tidak } \\
\text { obesitas }\end{array} \\
\%\end{array}$} & & & \\
\hline & $\mathrm{n}$ & $\%$ & $\mathbf{n}$ & & $\mathrm{n}$ & $\%$ & \\
\hline $\begin{array}{l}\text { baik } \\
\text { tidak }\end{array}$ & 26 & 22,81 & 88 & 77,19 & 114 & 100,00 & \multirow[t]{2}{*}{0.245} \\
\hline baik & 13 & 16,05 & 68 & 83,95 & 81 & 100,00 & \\
\hline Jumlah & 39 & 20,00 & 156 & 80,00 & 195 & 100,00 & \\
\hline
\end{tabular}


Pada tabel 4 dapat dilihat anak dengan obesitas sebagian besar juga memiliki pola makan yang baik yaitu 26 responden. Tetapi uji statistik menunjukkan hubungan yang tidak bermakna antara pola makan anak dengan kejadian obesitas dengan $p$ value $=0,245$ ( $p>0,05)$. Dapat disimpulkan bahwa pola makan anak tidak memiliki pengaruh terhadap kejadian obesitas pada anak. Hasil pada penelitian ini berbeda dengan hasil yang didapatkan pada penelitian yang dilakukan oleh Mujur tahun 2011 yang mendapatkan hubungan yang bermakna antara pola makan dengan berat badan yang lebih. Perbedaan ini dapat terjadi karena sangat banyaknya faktor risiko terjadinya obesitas. Dan hal-hal tersebut juga dipengaruhi oleh sosial dan budaya suatu daerah yang berpengaruh dengan gaya hidup masyarakat. ${ }^{11}$

\section{Hubungan Aktifitas Fisik dengan Kejadian Obesitas pada Anak}

Aktifitas fisik merupakan salah satu penggunaan energi (energy expediture) yang terbesar. Kekurangan pada pemakaian energi menyebabkan tidak seimbangnya antara pemasukan dan pemakaian energi sehingga banyak yang disimpan dalam bentuk jaringan lemak. Hal tersebut menyebabkan timbulnya obesitas pada seseorang. Pada penelitian ini, aktifitas fisik dinilai dengan menghitung waktu yang digunakan oleh responden untuk melakukan aktifitas fisik tanpa menilai intensitasnya. Hasilnya akan digolongkan menjadi "aktif" dan "kurang aktif".

Hasil penelitian ini menunjukkan bahwa lebih dari setengah responden memiliki aktifitas fisik yang aktif $(59,53 \%)$.

Tabel 5. Hubungan Pola Aktifitas Fisik dengan Kejadian Obesitas pada Siswa SD N 08 Alang Lawas, Padang

\begin{tabular}{|c|c|c|c|c|c|c|c|}
\hline \multirow{3}{*}{$\begin{array}{c}\text { Pola } \\
\text { aktifitas } \\
\text { fisik }\end{array}$} & \multicolumn{4}{|c|}{ Kejadian obesitas } & \multirow{2}{*}{\multicolumn{2}{|c|}{ Jumlah }} & \multirow{3}{*}{ P Value } \\
\hline & \multicolumn{2}{|c|}{ Obesitas } & \multicolumn{2}{|c|}{$\begin{array}{c}\text { tidak } \\
\text { obesitas }\end{array}$} & & & \\
\hline & $\mathbf{n}$ & $\%$ & n & $\%$ & $\mathbf{n}$ & $\%$ & \\
\hline \multirow{2}{*}{$\begin{array}{l}\text { Aktif } \\
\text { kurang } \\
\text { aktif }\end{array}$} & 18 & 15,38 & 99 & 84,62 & 117 & 100,00 & \multirow{2}{*}{0.048} \\
\hline & 21 & 26,92 & 57 & 73,08 & 78 & 100,00 & \\
\hline Jumlah & 39 & 20,00 & 156 & 80,00 & 195 & 100,00 & \\
\hline
\end{tabular}

Berdasarkan tabel 5 dapat dilihat bahwa aktifitas fisik pada sampel yang mengalami obesitas didapatkan lebih banyak sampel yang kurang aktif yaitu sebanyak 23 orang dibandingkan yang aktif. Terlihat terjadinya penurunan aktifitas fisik pada anakanak yang mengalami obesitas. Berdasarkan uji statistik yang dilakukan, ditemukan hubungan yang bermakna antara aktifitas fisik anak dengan kejadian obesitas atau dapat disimpulkan bahwa aktifitas fisik anak tidak memiliki pengaruh terhadap kejadian obesitas pada anak. Hal ini terlihat dari $p$-value $<0,05$ yaitu 0,048 . Hasil ini sesuai dengan hasil penelitian yang dilakukan oleh Hadi, dkk tahun 2005 yang mendapatkan aktifitas fisik memiliki hubungan yang bermakna dengan terjadinya overweight. ${ }^{10} \mathrm{Hal}$ ini juga didukung oleh pendapat Simatupang yang menyatakan bahwa besarnya hubungan antara pola makan dan aktivitas fisik, aktivitas fisik lebih berhubungan dengan terjadinya obesitas pada anak. ${ }^{5}$ Hal ini mencerminkan bahwa, pola hidup sedentary berkontribusi dalam terjadinya obesitas pada anak.

\section{KESIMPULAN}

Berdasarkan hasil penelitian dapat diambil kesimpulan bahwa kejadian obesitas pada SDN 08 Alang Lawas, Padang dikategorikan tinggi, sebagian besar siswa SDN 08 Alang Lawas, Padang memiliki ayah dan ibu dengan tingkat pendidikan menengah dan tingkat pendapatan di atas garis kemiskinan, pola makan baik, dan setengahnya memiliki pola aktifitas fisik yang aktif. Serta berdasarkan uji statistik terdapat hubungan yang bermakna antara kejadian obesitas pada anak dengan aktifitas fisik dan tidak terdapat hubungan yang bermakna dengan tingkat pendidikan ayah dan ibu, tingkat pendapatan orang tua, dan pola makan.

\section{DAFTAR PUSTAKA}

1. Yussac M, Artisto A, Cahyadi A, Andika CP, Astrid SD, Ayatullah K, Saptawati B, et al. Prevalensi obesitas pada anak usia 4-6 tahun dan hubungannya dengan asupan serta pola makan. Majalah Kedokteran Indonesia. 2007; 57(2):47-53.

2. Adiwinanto W. Pengaruh intervensi olahraga di sekolah terhadap indeks massa tubuh dan tingkat kesegaran kardiorespirasi pada remaja obesitas (tesis). Semarang: Universitas Diponegoro; 2008.

3. Depkes RI. Riset Kesehatan Dasar (RISKESDAS) 2010. Badan Penelitian dan Pengembangan Departemen Kesehatan RI 2010 (diunduh 18 Desember 2012). Tersedia dari: URL: HYPERLINK http://www.litbang.depkes.go.id/

4. Dinkes. Rekap hasil skrening kesehatan murid SD kota Padang tahun 2011. Dinas Kesehatan Kota Padang; 2011.

5. Simatupang, Romauli M. Pengaruh pola konsumsi, aktivitas fisik, dan keturunan terhadap kejadian obesitas pada siswa sekolah dasar swasta di kecamatan Medan Baru kota Medan (tesis). Medan: Universitas Sumatera Utara; 2008.

6. Direktorat Bina Gizi. Keputusan menteri kesehatan republik Indonesia nomor: 1995/Menkes/SK/XII/2010 tentang standar antropometri penilaian status gizi anak. Jakarta: Kementerian Kesehatan RI Direktorat Jenderal Bina Gizi 2011 (diunduh 5 Februari 2013). Tersedia dari: URL: HYPERLINK http://gizi.depkes.go.id/

7. Notoatmodjo S. Metodologi penelitian kesehatan. Jakarta: CV. Rineka Cipta; 2010.

8. Haryanto I. Faktor faktor yang berhubungan dengan obesitas (Z-Score $>2$ IMT menurut umur) pada anak usia sekolah dasar (7-12 tahun) di Jawa tahun 2010 (Analisis data RISKESDAS 2010) (tesis). Jakarta: Fakultas Kesehatan Masyarakat Universitas Indonesia; 2012.

9. BPS. Perkembangan beberapa indikator utama sosial-ekonomi Indonesia Agustus 2012. Jakarta: Badan Pusat Statistik; 2012.

10. Hadi SM, Sulityowati E, Mifbakhuddin. Hubungan pendapatan perkapita, pengetahuan gizi ibu dan aktivitas fisik dengan obesitas anak kelas 4 dan 5 di SD Hj. Isriati Baiturrahman kota Semarang. Jurnal Kesehatan Masyarakat Indonesia. 2005; 2(1):7-12 
11. Mujur, Andriardus. Hubungan antara Pola Makan dan Aktivitas Fisik dengan Kejadian
Berat Badan Lebih pada Remaja. Universitas Diponegoro. 2011. Diakses 4 Februari 2013. 